\title{
Bernard Mandeville and the 'economy' of the Dutch
}

\author{
ALEXANDER BICK \\ Princeton University
}

\begin{abstract}
Studies of Bernard Mandeville by economists and historians of economic thought have focused overwhelmingly on the problem of situating his work within the development of the theory of laissez-faire and evaluating his influence on major figures in the Scottish Enlightenment, especially Adam Smith. This paper explores Mandeville's economic thought through the lens of a very different transition: England's rapid growth following the Glorious Revolution and its gradual eclipse of Dutch economic hegemony. By situating Mandeville within an Anglo-Dutch context and carefully examining his comments on the Dutch in Remark Q of The fable of the bees, the paper shows the manner in which Mandeville's ideas both appropriated lessons from Dutch history and sought to revise ideas about the Dutch current among his English contemporaries. The paper thus sheds new light on core concepts in Mandeville's economic thought and permits exploration of an important moment in the development of political economy.
\end{abstract}

Keywords: Mandeville, Netherlands, Late Development, William Temple

JEL Classification: A11, B11, B31, N10, N13

The means by which poorer countries appropriate and adapt the technologies and ideas of their richer neighbors is one that has fascinated economists and economic historians for generations. In general, this problem has been addressed in what are somewhat pejoratively called "developing economies", but on rare occasions the tools and questions of development economics have been deployed in

AUTHOR's NoTE: An earlier version of this paper was submitted to Mary Morgan as a Masters Dissertation in Economic History at the London School of Economics. I would like to thank her for her inspiration and good judgment, along with Tim Hochstrasser, who first introduced me to Mandeville and provided essential guidance. Mario Bick, Diana Brown, Bill Bulman, Robert Darnton, Anthony Grafton, Jamie Kreiner, Peter Lake, Megan Lindsay, Harro Maas, Nealin Parker, Nick Popper, Eric Schliesser, Aaron Tugendhaft, and two anonymous referees offered challenging and helpful criticism. Responsibility for remaining errors of interpretation or fact is my own. 
the analysis of early modern Europe itself. In the late 1970s, the economic historian D. C. Coleman suggested, in a parenthetical remark, that, "a late start hypothesis for England might be worth investigating" (Coleman 1977, 197). This idea drew inspiration from the earlier work of F. J. Fisher, who argued that England's economy in the Tudor and Stuart periods was in important respects "underdeveloped" (Fisher 1958). In the paper that follows, I will pursue this line of inquiry by examining the model of commercial development that the Netherlands presented to English political economists in the late 17 th and early 18th centuries, and the manner in which this model changed as England began to surpass Dutch economic hegemony.

This territory is in some ways familiar thanks to the detailed and sophisticated studies of Charles Wilson (1984), Joyce Appleby (1978), David Ormrod (2003), and others. My paper will build on their important work, but will focus on a figure that has rarely been examined in this context: the Dutch-born doctor and London émigré, Bernard Mandeville. In particular, I would like to look closely at Remark $\mathrm{Q}$, a lengthy footnote in the manner of Pierre Bayle that Mandeville included in the first edition of his famous Fable of the bees: private vices, publick benefits, published in 1714 (Mandeville 1929). ${ }^{1}$ There, Mandeville offered a wide-ranging discussion of the differences between the English and Dutch economies and suggested the lessons that the Dutch could, andmore importantly-should not, provide to England. As I will show, his treatment of the interplay between consumption, natural resources, and commercial policy revised important ideas current in England concerning the lessons of Dutch history. Mandeville's text, along with the criticism it received, helps us to understand the complex problems involved in the longer-term appropriation and translation of models between these two commercial rivals.

My approach thus places Mandeville firmly within what, borrowing and extending a concept from Jonathan Israel (1991), might be called the longer durée of the "Anglo-Dutch Moment". As a Dutchman and foreigner in London, Mandeville was an observer and minor actor in the great drama of England's political, commercial, and financial

\footnotetext{
${ }^{1}$ All citations to this text will be to the authoritative F. B. Kaye edition, published by Oxford University Press in 1929 and subsequently reprinted by the Liberty Fund. The text that appears in the Kaye edition as "Remark Q" originally appeared as "Remark P" in the first edition of the Fable of the bees, printed for J. Roberts in 1714. For a publishing history of the Fable, see Kaye in Mandeville (1929, I, xxxiii-xxxvii; and II, 386-400).
} 
transformation following the Glorious Revolution of 1688-1689. His analysis of core problems in political economy reflects his mixed identity to a degree that has received remarkably little attention among economists and historians of economic thought. Indeed, for much of the past century, in-depth studies by these scholars primarily focused on the rather abstract problem of situating Mandeville's work within the development of the theory of laissez-faire and evaluating his influence on major figures in the Scottish Enlightenment, especially Adam Smith. ${ }^{2}$ While this debate helped to clarify a number of important aspects of Mandeville's ideas on the balance of trade and the role of government, as well as his contributions to the theory of unintended consequences, it confined discussion to Mandeville's place within a formal theoretical transition of which he by definition could have been only dimly aware.

Here I will look instead at a problem of which Mandeville was keenly aware: England's rapid commercial growth and her changing relationship to the Netherlands in the early 18th century. My paper begins by reviewing Mandeville's ideas on luxury consumption in order to provide a sense of his approach to the London economy and to establish some of the ways that he employed his unusual comparative perspective. ${ }^{3}$ I then turn to his analysis of the differences between England and the Netherlands in Remark Q. What, according to Mandeville, were the proper lessons for England to draw from Dutch commercial success? How did these lessons challenge existing interpretations of Dutch history, and what more general principles did Mandeville offer to explain the flourishing of commercial societies?

\section{MANDEVILLE AND THE LONDON ECONOMY}

Although Mandeville's later biography remains frustratingly incomplete, a number of recent studies by historians in England and the Netherlands have helped to establish the details of his early life with some precision (Dekker 1992; Goldsmith 1992; Cook 1999, 2007). Born in Rotterdam in

\footnotetext{
${ }^{2}$ The entire course of this debate to the mid-1970s is reviewed in Landreth (1975). For two particularly illuminating and contrasting viewpoints, see Viner (1958); and Hayek (1978).

${ }^{3}$ A great deal has been written on the "luxury debates" that raged across Europe in the mid-18th century. My paper overlaps with this literature in important ways, but focuses more closely than is often done on the problem of saving and its implications for the ways that English writers understood Dutch economic development in the Netherlands. On the luxury debate, see especially Hont (2006). For analysis of England's "Consumer Revolution", including discussion of Mandeville's ideas on consumption, see the introductions to the edited volumes by Brewer and Porter (1993); and Berg and Clifford (1999).
} 
1670, Mandeville came from a family of physician-magistrates well connected in city politics. He studied philosophy, perhaps even meeting the skeptic and editor Pierre Bayle, and then medicine, completing his doctorate at the University of Leiden in 1691. His dissertation, which examined disorders of the stomach, bore the intellectual imprint of the French-born philosopher René Descartes, who lived in the city in the 1630 s and 1640s and whose ideas contributed to a vigorous climate of radical philosophical materialism that lasted well into the 18th century. In addition to his studies, Mandeville was something of an agitator: in 1690, he and his father were implicated in the Costerman affair, a political conflict that swept Rotterdam and ultimately led to his father's expulsion from the city. Sometime in the early 1690s Mandeville left the Netherlands for good, arriving in England no later than November 1693, when he was cited by the College of Physicians for practicing medicine without their permission.

Mandeville's arrival in London came fresh on the heels of the Glorious Revolution, when a Dutch army invaded England, deposing the government of James II and ultimately installing the Dutchman William III and his English wife, Mary Stuart, as joint sovereigns. This event ushered in a long period of Anglo-Dutch political and military cooperation against France that drew England into Continental affairs and dramatically increased the financial burden on English taxpayers. It also led, in the summer of 1694, to the establishment of the Bank of England as a vehicle with which to raise additional money and buttress government credit (Dickson 1967).

As the pamphlet literature of the period amply demonstrates, the explosion of government debt, the increasing importance of "city" financiers in national politics, and the profits in land and money that accrued to some of William's chief Dutch advisors exposed William to charges of corruption and criticism that his government was siphoning English resources for an alliance that was more in the interest of the Netherlands than England itself (Rose 1999). As the Tory MP Charles Davenant put in 1701, "everyone is on the scrape for himself, without any regard to his country, each cheating, raking, and plundering what he can, and in a more profligate degree than ever was known" (Davenant 1771, II, 301).

To these cries of corruption and moral decay Mandeville offered both a defense of the Revolution settlement and an analysis of the London economy that made moral depravity a central component of 
commercial growth. If, as H. T. Dickson has argued, Mandeville kept party politics at arm's length, his general orientation is fairly clear (Dickson 1974; Kramnick 1992; Goldsmith 1999). In a 1703 pamphlet, The pamphleteers: a satyr, Mandeville defended William's legacy against detractors, arguing that the recently deceased King had successfully protected England from popery and that the "gaudy crown he wore" was not worth "one-tenth the indignities that he bore" (Mandeville 1703, 6). ${ }^{4}$ Two years later, in 1705, Mandeville published another work, The grumbling hive, or knaves turn'd honest, a satirical pamphlet in doggerel verse that would later serve as the core of The fable of the bees. Here he famously compared England to a thriving beehive, "well stockt with Bees/That liv'd in Luxury and Ease" (Mandeville 1929, 24). Greed, corruption, and decadence could be found at all levels of the social hierarchy, but these same characteristics made the hive rich. Mandeville's poem thus played on the image of bees as busy and industrious (Johnson 1966; Hundert 1994, 24-29), while inverting their traditional association with social order: "Every Part was full of Vice", Mandeville wrote, "Yet the whole Mass a Paradise" (Mandeville 1929, 24).

Some scholars believe that this pamphlet was intended primarily to deflect charges of corruption and fraud that had been leveled against England's military commander on the Continent, John Churchill, the first Duke of Marlborough (Kramnick 1992, 201). But the message of The grumbling hive was more profound: with its new constitutional monarchy, densely populated capital, and industrious working poor, Mandeville believed that England was poised to become the envy of the world. The vices that he so relentlessly exposed might be unfortunate, but they were inescapable in a flourishing commercial society, and could not be eliminated without undermining growth itself. Here Mandeville drew inspiration from a number of scholars in England and the Netherlands who argued that the human passions could be managed in a way that would maintain or even promote social order. ${ }^{5}$ Thus Mandeville argued that:

\footnotetext{
${ }^{4}$ The pamphleteers: a satyr (London 1703): To my knowledge, Mandeville has not been definitively identified as the author of this work, but the internal evidence supports attribution and most scholars continue to treat the work as his. The British library lists the pamphlet's author as Mandeville.

5 Of particular importance were Thomas Hobbes, Pierre Bayle, the Leiden cloth merchant Pieter de la Court, and Baruch Spinoza. For their respective influences on Mandeville's thought, see F. B. Kaye's introduction to the Fable (1929, I, xxxix-cxiii); Hundert (1994); and Cook (1999). For the broader outlines of Dutch Republican theory, and the role of the passions in de la Court and Spinoza, see Kossman (1960).
} 
The Root of Evil, Avarice,

That damn'd ill-natur'd baneful vice,

Was Slave to Prodigality,

That Noble Sin; whilst Luxury

Employ'd a Million of the Poor,

And odious Pride a Million more:

Envy it self, and Vanity,

Were Ministers of Industry (Mandeville 1929, I, 25).

If the terms were pitched to offend, the mechanism here was fairly simple: avarice, which led individuals to work hard and to accumulate resources, was balanced by prodigality, or spending beyond one's means, which would cause these same resources to be put back into circulation. The spending of the rich would thus create work for England's poor. It was a formulation that put urban, luxury consumption at the center of the economic system. ${ }^{6}$ In the early $1690 \mathrm{~s}$, the successful London merchant and real estate developer Nicholas Barbon had made a similar argument, writing that the "chief causes promoting trade are the industry of the poor and the liberality of the rich". Especially important was consumption of fashions and other goods that, as Barbon put it, "serve the pomp of life". Prodigality might be bad for the individual, but it was good for trade (Barbon 1690, 36; Letwin 1963; Finkelstein 2000).

Mandeville appropriated these controversial ideas and presented them to his adopted countrymen in a language that was rich in meaning and would have been familiar to many English readers: prodigality was, after all, a vice to which the English were thought to be particularly prone. ${ }^{7}$ Avarice, by contrast, was chiefly associated with the Dutchperhaps most memorably in Daniel Defoe's catalogue of national stereotypes in The true-born Englishman, published just five years before The grumbling hive, in 1700 (Defoe 1700, 9). The productive

\footnotetext{
${ }^{6}$ Unlike his contemporary Daniel Defoe, who travelled extensively throughout England and reported on the diversity of the country's industries, I am aware of no evidence that Mandeville ever strayed more than a few miles from London. As the city was, in F. J. Fisher's memorable phrase, a "center of conspicuous consumption", this may help to account for the disproportionate role Mandeville devoted to the demand-side of the English economy. See Fisher (1990).

${ }^{7}$ See, for instance, Thomas Mun: "this great plenty which we enjoy, makes us a people not only vicious and excessive [but also] wasteful of the means we have" $(1664,178)$. Although these words were likely written in the early 1620s, Mun's book continued to be read later, and such lamentations concerning the lack of restraint practiced by English consumers were commonplace throughout the 17th century.
} 
alliance between the two passions thus mirrored the productive alliance between England and the Netherlands themselves. In this sense, Mandeville's was a very specific portrait of London; one that wove together allegiance to the government and tolerance for the ethical contradictions that he believed were implicit in its burgeoning consumer economy. Unless the English would prefer to return to poverty and simplicity, they must set aside their incessant "grumbling" and accustom themselves to the pace and character of rapid commercial development $-\mathrm{a}$ process that Mandeville had presumably encountered first-hand as a young man living in Rotterdam and Leiden, two of the Netherlands' most important centers of trade and industry.

\section{REMARK Q AND THE DUTCH 'PATTERN'}

The lessons of the Dutch experience were not so simple, however. As F. B. Kaye, editor of Mandeville's Fable of the bees, pointed out long ago, Mandeville's defense of luxury consumption in The grumbling hive presented something of a paradox, in that it squarely contradicted the view-often repeated by English writers-that the Dutch economic miracle of the 17th century had been built, at least in part, on the Dutch people's frugal spending habits and their careful, even obsessive attention to saving (Mandeville 1929, I, 188n). Mandeville's response to this paradox provides a fascinating window into his ideas about economic growth and the manner in which he differentiated processes of commercial development in each country.

If, as Mandeville later quipped, the English knew less about the Netherlands than might be expected of so close a neighbor and ally (Mandeville 1709, 137), many among them were extremely keen to understand the sources of Dutch wealth and the ways in which Dutch examples might inform policy in England. As Joyce Appleby (1978) has demonstrated, the Dutch economy exercised a profound influence on English political economists and served as an important "source of evidence" for their analysis of the English economy. To cite but one of many examples, Josiah Child, perennial Director of the East India Company, enumerated no less than fifteen specific lessons that could be drawn from Dutch commercial practice in his widely distributed Brief observations concerning trade and interest of money, published in 1668 and then reprinted and enlarged in 1689, 1690, 1693, and 1694 (Child 1668, 3-6; Ormrod 2003, 313). These lessons-which included the promotion of shipping, the participation of merchants on Dutch 
councils of state, and the advantages of a low rate of interest-were, in Child's words, "sufficiently obvious, and in a great measure imitable by most other Nations, but more easily by us of this Kingdom of England" (Child 1668, 3).

Within the formal ranks of government, interest in the Dutch was equally intense. Senior English officials such as George Downing and Joseph Williamson, each of whom served Charles II in the 1660s and 70s, eagerly collected information on Dutch trade and industry, translating Dutch pamphlets and, on at least one occasion, sending spies to steal and copy secret government documents (Scott 2004; Wilson 1984, 166-175). While these two individuals' work remained largely outside the public view, Sir William Temple's popular Observations upon the united provinces of the Netherlands, first published in 1672, reached a much broader audience (Temple 1972; Haley 1986). As ambassador to The Hague from 1668-1670, Temple was friendly with Holland's Grand Pensionary, Johan de Witt, and opposed to the third Anglo-Dutch war that resulted in his death. Temple's book offered an elegant, authoritative, and highly sympathetic survey of Dutch culture, history, religion, politics, and trade. It quickly became a standard reference on the Dutch, and by 1700 was already in its eighth printing.

Important to this literature, and to Temple's account in particular, was the image of the Dutch as a frugal, parsimonious people who had built a thriving economy by shunning luxuries and profiting from the prodigality of their neighbors. Child, for instance, placed "parsimonious and thrifty living" sixth on his list, noting that, "a merchant of one hundred thousand pounds estate with them, will scarce expend so much per annum, as one of fifteen hundred pounds estate in London" (Child $1668,4)$. Temple was equally impressed, arguing that even if trade was their main activity, the "true ground" of Dutch success lay with their "industry and parsimony":

For never a Countrey traded so much, and consumed so little: They buy infinitely, but 'tis to sell again [...] They are the great masters of the Indian Spices, and of the Persian Silks; but wear plain Woollen, and feed upon their own Fish and Roots. Nay, they sell the finest of their own Cloath to France, and buy coarse out of England [...] They send abroad the best of their own Butter into all parts, and buy the cheapest out of Ireland, or the north of England, for their own use. In short, they furnish infinite luxury, which they never practice, and traffique in Pleasures which they never taste (Temple 1972, 119). 
If Mandeville was to establish the credibility of the argument he advanced in The grumbling hive, he needed to address this supposed Dutch virtue and the author who had so conspicuously celebrated it. In 1714, when Mandeville added a preface, explanatory notes, and other new material to the original poem and reissued it as The fable of the bees, he did just this, devoting Remark Q to frugality and the historical lessons of the Dutch.

Mandeville made two main arguments: the first sought to undermine the idea that the Dutch were in fact as frugal as many Englishman supposed. The second attempted to show that what restraint was practiced in the Netherlands owed less to virtue than it did to necessity, and thus that the absence of this necessity in England created a novel situation in which consumption could play an entirely different role than it had in his own country.

It was true, Mandeville conceded, that the Dutch were more modest than some of their neighbors on the continent. As a commonwealth, with greater equality of income, one could not expect to find in the Netherlands princely palaces or the sorts of display associated with the court. Instead money was spent elsewhere. "In Pictures and Marble they are profuse", Mandeville reported, and "in their Buildings and Gardens they are extravagant to Folly" (Mandeville 1929, I, 187).

As Simon Schama's analysis of Dutch consumption and culture has shown, this assessment was broadly accurate. Home furnishings and other luxury goods were available and eagerly bought up in every major Dutch city, especially Amsterdam, where Melchior Fokkens, a Dutch gazetteer, in 1665 noted "houses full of priceless ornaments [...] splendid alabaster columns, floors inlaid with gold, and the rooms hung with valuable tapestries or gold or silver-stamped leather worth many thousand of guilders" (Schama 1987, 303). Consumption was more discreet, perhaps, kept indoors or partially concealed, but it was not thereby any less prodigious. Temple could praise the Dutch for keeping the same fashions longer than others, and for wearing apparently simple black clothing, but Schama points out that "the black was very often satin or velvet, sometimes discretely trimmed with fur" (Schama 1987, 310).

If the Dutch were in general still more frugal than the English, the second component of Mandeville's argument was designed to show how this was a necessary response to the natural, economic, and political 
constraints the Dutch faced. Each of these, Mandeville believed, made luxury consumption more difficult and a higher degree of saving imperative. Indeed, Mandeville was at pains to demonstrate to his English audience the terrible burdens under which the Dutch labored. In a parallel passage in a separate work, published in 1709, Mandeville sought to dispel criticisms that the English were paying a disproportionate amount in taxes to support the war:

If, I say, some of our [English] People should know how they [the Dutch] are oblig'd to pay certain Sums, at which they are rated for using Salt, and Soap, whether they consume little or much; how every Family, that will drink Tea, Coffee, or Chocolate, must pay a great Tax for it, tho' they had but one Dish of any of the three in the whole Year: Should they consider all this, and that the very Cows pay for having Horns, they would think our Burden much lighter than theirs, and cry out, Blessed England! (Mandeville 1709, 139).

Indeed, modern research in economic history has estimated that the Dutch paid two and a half times as much in taxes as their counterparts in England, a factor that placed dramatic constraints on the possibilities for growth (Ormrod 2003, 307).

But taxes were only one part of a larger story. In a passage that may have influenced Mandeville directly, Charles Davenant suggested in 1698 that the Dutch might have been forced into thrift by the constant threat of invasion by land and their precarious natural environment. The Dutch, he wrote "are continually forced, in a manner, to pump for life, and nothing can support them but the strictest œconomy imaginable, both in private and in public" (Davenant 1771, 390). Although he viewed luxury spending with considerable skepticism, Davenant recognized that England was an island with abundant natural produce, and thus that its people could probably afford to indulge in greater luxury than their neighbors:

But our case is far from being the same [as the Dutch]; we are not easily invaded; the expense of our government in time of peace, is much less than theirs; we have a large and fertile country, and a great native product; so that the whole public of this kingdom may grow rich, though the people [...] are more luxurious than in other nations (Davenant 1771, 390).

And perhaps, Davenant continued, "it is not impossible, but that our industry would be less active, if it were not awakened and incited by 
some irregular appetites, which are more easily found fault with than cured" (Davenant 1771, 390-391). ${ }^{8}$

In Remark Q, Mandeville developed this observation into a complex portrait of the relationship between the passions, natural resource endowments, policy, and growth. Men may initially differ in temperament, and thus be disposed to covetousness, prodigality, or saving, he argued, but "if anything ever draws 'em from what they are naturally propense to, it must be a Change in their Circumstances or their Fortunes". The most important of these circumstances were the "Fruitfulness and Product of the Country, the Number of Inhabitants, and the Taxes they are to bear" (Mandeville 1929, I, 184). If the first is great, but the number of people and the taxes low, nothing will progress beyond a happy and slothful ease:

Man never exerts himself but when he is rous'd by his Desires: While they lie dormant, and there is nothing to raise them, his Excellence and Abilities will be forever undiscover'd, and the lumpish Machine, without the Influence of his Passions, may justly be compar'd to a huge Wind-mill without a breath of Air (Mandeville 1929, I, 184).

But shift things around through laws and "good management", and then people's dispositions will change. It is worth quoting Mandeville at length on this point:

Would you render a Society of Men strong and powerful, you must touch their Passions. Divide the Land, tho' there be never so much to spare, and their Possessions will make them Covetous: Rouse them, tho' but in Jest, from Idleness with Praises, and Pride will set them to work in earnest: Teach them Trades and Handicrafts, and you'll bring Envy and Emulation among them: To increase their Numbers, set up a Variety of Manufactures, and leave no Ground Uncultivated; Let Property be inviolably secured, and Privileges equal to all Men; Suffer no body to act but what is lawful, and every body to think what he pleases; for a Country where every body be maintained that will be employ'd, and the other Maxims are observ'd must always be throng'd and can never want People [...] But would you moreover render them an opulent, knowing and polite nation, teach 'em Commerce with Foreign Countries, and if possible get into the Sea, which to compass spare no Labour nor Industry, and let no Difficulty deter you from it: Then promote Navigation, cherish the Merchant, and encourage Trade in every Branch of it; this will bring

\footnotetext{
${ }^{8}$ Mandeville's debt to this passage was first proposed by F. B. Kaye (Mandeville 1929, I, $187 n)$
} 
Riches, and where they are, Arts and Sciences will soon follow (Mandeville 1929, I, 184).

Thus, the Dutch had achieved their remarkable success, through effectively managing the passions, attracting large numbers of people, and encouraging industry and trade. If poor land and high taxes had made the Dutch frugal, this was no virtue. In fact, Mandeville argued, these constraints had if anything only encouraged the Dutch to adopt aggressive tactics to improve their situation. To admit that frugality was necessary under the circumstances was a very different thing than to claim that it had made the Dutch rich in the first place. Frugality was thus only an effect, a response to circumstance rather than an economic virtue.

But in England, circumstances were more favorable and frugality unnecessary. In his classic work of republican and commercial theory, The true interest and political maxims of Holland and West-Friesland, published in 1662, Pieter de la Court had written enviously of England's situation. Asking, "why the great inconveniences of Taxes and Wars that we have laboured under, have not occasioned the Fishing, Manufactury, Traffick, and Navigation, to settle and fix in other Countries", he cited England,

where if all be well considered they have had far greater Advantages of Situation, Harbours, a clean and bold Coast, favorable Winds, and Opportunity of transporting many unwrought Commodities, a lasting Peace, and a great freedom from Taxes than we have (de la Court, 1702, 45).

De la Court's answer to this question was historical, citing the higher taxes and other restrictions placed on foreigners in London at the time of the fall of Antwerp, in 1585. But the implication was that circumstances might change at any time. With government support for trade, taxes lower than in the Netherlands, and abundant resources, England was, by the last decade of the 17th century, in the superior position.

As Mandeville saw it, the English could now afford to rouse their passions through luxury if it was economic growth they desired. Whereas the Dutch were running out of land and had to import much of their food, the English were nearly agriculturally self-sufficient and there was still plenty of uncultivated land available. Here his argument stressed the advantages of England's underdevelopment, or what we 
might call her "relative backwardness". Elsewhere in the Fable of the bees, in fact, Mandeville suggested that work still remained for 100,000 poor for "300-400 years" for England to bring all of its territory into productive use (Mandeville 1929, I, 318). These figures probably would not bear contemporary scrutiny, but the basic analysis was sound: despite considerable progress during the last third of the 17th century, England had not yet achieved the level of intensive resource usage-in terms of land-reclamation, the construction of canals, and the use of wind-power-for which the Netherlands was famous. And the fact that wages were lower in England than in the Netherlands suggests that labor was more abundantly available, as well. What was missing was circulating capital.

Mandeville's argument was not simply that the English could afford to consume, but that consumption would actually contribute to national wealth. In England, the relative paucity of capital resulted in interest rates higher than those in the Netherlands, which had abundant capital and already had nearly achieved what Adam Smith would later describe as a "full complement of riches" (Smith 1963, I, 76). The Bank of England was beginning to address this problem, but Mandeville evidently believed that the additional reserves of money cautiously squirreled away in chests could be put to better use. It is perhaps only in this context that we can begin to see the logic in Mandeville's otherwise outrageous claim that stealing from the miser would benefit the public good: without the general circulation of capital-by theft or mere profligacy-England's full range of human and natural resources could not be brought into productive employment. Luxury consumption was an important part of this vision, but it was only one part among many.

\section{WILLIAM TEMPLE'S LEGACY}

This interpretation of England's potential and the lessons of the Dutch model were not universally accepted among Mandeville's contemporaries. Responses to Mandeville's theory of luxury consumption have received considerable attention from scholars, but one response in particular helps us to understand the ways in which consumption fit within a broader disagreement concerning the historical lessons of the Dutch. In an anonymous pamphlet published in 1725, in direct response to the second edition of Mandeville's Fable of the bees, which had been released in the previous year, the lawyer George Bluett took direct issue with Mandeville, in part by attacking his use of William 
Temple (Bluett 1725).9 In his discussion of Dutch spending habits, Mandeville had attempted to show that Temple's Observations had been written during a time of particular distress:

The Nation I speak of was never in greater Straits, nor their Affairs in a more dismal Posture since they were a Republick, than in the Year 1671, and the beginning of 1672 . What we know of their CEconomy and Constitution with any Certainty has been chiefly owing to Sir William Temple, whose Observations upon their Manners and Government, it is evident from several Passages in his Memoirs, were made about that time. The Dutch indeed were then very frugal; but since those Days and that their Calamities have not been so pressing [...] a great Alteration has been made among the better sort of People in their Equipages, Entertainments, and whole manner of living (Mandeville 1929, I, 189).

This interpretation allowed Mandeville to argue that, once free from the burdens of war, the Dutch took to consuming much as people in England were doing at present. Mandeville thus tipped his hat to Temple as the chief source of information on the Dutch at the same moment that he undermined Temple's credibility by suggesting that his observations had been distorted by the unusual events taking place during Temple's tenure in the Netherlands.

Bluett was wholly unconvinced by this reading. "Was there ever a more injudicious Remark?" Bluett asked, continuing:

In what a perverse manner must he have read the Author he quotes. In the very same Paragraph in which Sir William Temple tells him, that his observations were made about that Time, he ascribes the Decay of their Wealth to the Luxury he had for several Years observed to be growing among them (Bluett 1725, 45).

Moreover, Bluett argued that the necessity under which the Dutch labored did not make frugality any less of a virtue:

If the Dutch in their present Condition are oblig'd to be more frugal than their Neighbours, from the vast Expense they are at in Repairing their Dykes, the Weight of other taxes, and the Scantiness of their Dominions; would not the same Frugality in their Neighbours, who have a greater Extent of Land, and no such

\footnotetext{
${ }^{9}$ F. B. Kaye attributes this pamphlet to the London lawyer George Bluett. See his comments excerpted in (Stafford 1997, 229-230).
} 
Demands of Expense, keep them in a Condition still proportionately above them, and continue them still proportionately richer?

How was it, in other words, Bluett asked, that frugality could be such a "whimsical Virtue, that it always makes a poor Country [the Netherlands] rich, and a rich Country [England] poor?" (Bluett 1725, 50).

On point after point Bluett provided a meticulous, logical critique of Mandeville's thought, based on a close reading not only of the Fable of the bees, but also several other of Mandeville's books and even some of his favorite sources (Stafford 1997). Bluett's orientation was traditional. He likened the national economy to the economy of the household, as generations of English mercantilists had done before him, and thereby concluded that consumption could only serve to drain the national coffers. Spain's descent during the 17th century and Temple's account of both the Dutch rise and the early stages of their decline provided his evidence. Bluett's reading of Temple was faithful, in so far as Temple held a neo-Polybian view of the cyclical cresting and falling of empires as frugality gave way to luxury and decadence. ${ }^{10}$ Temple's Observations thus helped Bluett to put Mandeville's interpretation of London's consumer society into historical perspective: "If Vice in general, and luxury in Particular, be the Road to Wealth", Bluett concluded, with a perhaps overly generous sense of irony, "we [in England] bid fair for growing prodigiously Rich” (Bluett 1725, 52).

That Mandeville's assessment seems to have more closely captured the spirit of commercial development in early 18th century England says nothing about the deceptive manner in which he tried to get around the lessons in Temple's Observations. But Mandeville read Temple in another way, as well; one that helps us to better understand the overall thrust of his ideas. Later in Remark Q, Mandeville drew on Temple's ideas concerning the relationship between a people's disposition and their passions:

All Men, as Sir William Temple observes very well, are more prone to Ease and Pleasure than they are to Labour, when they are not prompted to it by Pride or Avarice, and those that get their Living by daily Labour, are seldom powerfully influenc'd by either: So that they

\footnotetext{
${ }^{10}$ As Istvan Hont has argued, Temple balanced this classically-inspired interpretation of the Netherlands' economic troubles with an analysis of the ethically-neutral effects of increasing competition from other trading nations, including England. See Hont $(1990,55)$.
} 
have nothing to stir them up to be serviceable but their Wants, which it is Prudence to relieve, but Folly to cure (Mandeville 1929, I, 194).

Here Mandeville had read Temple carefully and was not attempting to deceive. Instead, he used Temple's ideas to show that people were not inclined to work without some sort of stimulus, or anticipated reward. If this reward could in the Netherlands be only very limited, due to the difficult conditions there, in England it could be that much greater.

Where Bluett had tried to analyze the economy from the perspective of virtue and vice, and thus gave the same prescription for England as that which had worked for the Netherlands, Mandeville followed the strand in Temple's Observations that explored the ways that virtues and vices developed in intimate relation with the natural environment and institutional context. Since this environment was different in England, a different sort of disposition could be expected to assist its people. Man's nature might be "everywhere the same", as Temple put it, but his manners and customs differed from place to place (Temple 1972, 80, 88-94). This was an observation that presumably came less easily to Bluett than to Mandeville, who had made the same journey between England and the Netherlands as Temple, though twenty-five years later and in the reverse direction.

\section{CONCLUSION}

In the space of Mandeville's lifetime, England was transformed into Europe's largest economy, and the Netherlands, though still growing, had lost its position of pre-eminence (Omrod 2003, 307-309). By 1740, seven years after Mandeville's death, an English writer could say that now "England could only borrow money where once she had sought inspiration" (Feingold 1996, 259). The analysis in this paper suggests that this inspiration was itself multi-faceted, and changed over time. In the context of England's rapid commercialization in the first decades of the 18th century, older lessons gleaned from authors like Child and Temple needed to be re-evaluated and new ones given firm footing. Mandeville's Remark Q might be seen in this light, and further taken as an indication that the historical lessons of the Dutch economy continued to animate public discussion in England well into the 1720s, if not later.

Mandeville's analysis of the differences between English and Dutch economies led him to articulate a theory of commercial development 
that rested heavily on commercial policy and the role of government in managing men's passions. The Dutch had become rich through careful attention to merchant interests, investment in shipping and navigation, intensive exploitation of land, religious toleration, and protection of private property. History showed the importance of these measures and thus buttressed the initiatives of those in England who aimed to institute or protect similar policies at home. Luxury consumption could be an important ingredient not because it was universally beneficial, but because England's circumstances facilitated a positive relationship between indulgence and employment that circumstances in the Netherlands simply could not support. It is this combination of probing psychological analysis, observation, and comparative history that made Mandeville's ideas so powerful, and which led him to the conclusion that England had the capacity to exceed, rather than simply approximate, the model offered by the Dutch. ${ }^{11}$

One last issue requires attention, and may be taken as a sort of postscript. In their classic studies of "late development", Walter Rostow and Alexander Gerschenkron generally assumed a stable industrial model, towards which countries in Eastern and Central Europe, Latin America, Asia, or Africa would strive (Rostow 1960; Gerschenkron 1962). It was Gerschenkron's great innovation to suggest that the form taken by development in a relatively backward country would differ in important respects from the processes of growth in the most advanced economies, directly in proportion to their level of backwardness. In particular, he emphasized the variability of speed, industrial scale, and the role of banks. But he also suggested that late development would require an ideology; a set of principles that could break routine and provide ordinary citizens with faith that improvement lay ahead (Gerschenkron 1960, 24). Of course, Mandeville knew nothing of the Industrial Revolution and even less of the ideological programs that would animate industrialization in the 19th and 20th centuries. But his work might be interpreted as having counseled a similar kind of faithin the improving qualities of commercial development and the ability of the English state to harness men's private vices, as his subtitle famously argued, for public benefit.

\footnotetext{
${ }^{11}$ It is clear that Mandeville saw England's potential as vast; it would be interesting to know also whether he saw this potential as posing a direct threat to his native country and its economic and political future. If he did, I have found no indication to this effect in his writings, though it is of course possible that Mandeville would not have addressed such concerns to his English audience.
} 


\section{REFERENCES}

Appleby, Joyce. 1978. Economic thought and ideology in seventeenth-century England. Princeton: Princeton University Press.

Barbon, Nicholas. 1690. A discourse of trade. London: Printed by Tho. Milbourn.

Berg, Maxine, and Helen Clifford (eds.). 1999. Consumers and luxury: consumer culture in Europe 1650-1850. Manchester: Manchester University Press.

Bluett, George. 1725. An inquiry whether a general practice of virtue tends to the wealth or poverty, benefit or disadvantage of a people. London: Printed for R. Wilkin.

Child, Josiah. 1668. Brief observations concerning trade and interest of money. London: Printed by Elizabeth Calvert, and Henry Mortlock.

Coleman, D. C. 1977. The economy of England, 1450-1750. Oxford: Oxford University Press.

Cook, Harold. 1999. Bernard Mandeville and the therapy of 'the clever politician.' Journal of the History of Ideas, 60 (1): 101-124.

Cook, Harold. 2007. Matters of exchange: commerce, medicine, and science in the Dutch golden age. New Haven: Yale University Press.

Court, Pieter de la. 1702. The true interest and political maxims of Holland and WestFriesland. London.

Davenant, Charles. 1771. The political and commercial works, ed. Sir Charles Whitworth, 5 Vols. London: Printed for R. Horsfield, T. Becket, P. A. de Hondt, T. Cadell, and T. Evans.

Defoe, Daniel. 1700. The true-born Englishman. London.

Dekker, Rudolf. 1992. 'Private vices, public virtues' revisited: the Dutch background of Bernard Mandeville. History of European Ideas, 14 (4): 481-498.

Dickinson, H. T. 1975. The politics of Bernard Mandeville. In Mandeville studies: new explorations in the art and thought of Dr. Bernard Mandeville, ed. Irwin Primer. The Hague: Martinus Nijhoff, 80-119.

Dickson, P. G. M. 1967. The financial revolution in England: a study in the development of public credit, 1688-1756. London: Macmillan.

Feingold, Mordechai. 1996. Reversal of fortunes: the displacement of cultural hegemony from the Netherlands to England in the seventeenth and early eighteenth centuries. In The world of William and Mary: Anglo-Dutch perspectives on the revolution of 1688-89, eds. Dale Hoak, and Mordechai Feingold. Stanford: Stanford University Press, 234-261.

Finkelstein, Andrea. 2000. Harmony and the balance: an intellectual history of seventeenth-century economic thought. Ann Arbor: University of Michigan Press.

Fisher, F. J. 1958. The sixteenth and seventeenth centuries: the dark ages in English economic history? Economica, 24 (93): 2-18.

Fisher, F. J. 1990. The development of London as a centre of conspicuous consumption in the sixteenth and seventeenth centuries. In London and the English economy 1500-1700, eds. P. J. Corfield, and N. B. Hart. London: Hambledon Press, 105-118.

Gerschenkron, Alexander. 1962. Economic backwardness in historical perspective. Cambridge: Harvard University Press.

Goldsmith, M. M. 1992. Bernard Mandeville and the virtues of the Dutch. Dutch Crossing, 48: 20-38. 
Goldsmith, M. M. (ed.). 1999. By a society of ladies: essays in the female tatler, by Bernard Mandeville. London: Thoemmes.

Haley, K. H. D. 1986. An English diplomat in the Low Countries: Sir William Temple and John de Witt, 1665-1672. Oxford: Oxford University Press.

Hayek, Friedrich August von. 1978. New studies in philosophy, politics, economics, and the history of ideas. Chicago: University of Chicago Press.

Hont, Istvan. 1990. Free trade and the economic limits to national politics: neoMachiavellian political economy reconsidered. In The economic limits to modern politics, ed. John Dunn. Cambridge: Cambridge University Press, 41-120.

Hont, Istvan. 2006. The early Enlightenment debate on commerce and luxury. In The Cambridge history of eighteenth-century political thought, Vol. I, eds. Mark Goldie, and Robert Wokler. Cambridge: Cambridge University Press, 379-418.

Hundert, E. J. 1994. The Enlightenment's fable: Bernard Mandeville and the discovery of society. Cambridge: Cambridge University Press.

Israel, Jonathan (ed.). 1991. The Anglo-Dutch moment: essays on the glorious revolution and its world impact. Cambridge: Cambridge University Press.

Johnson, James W. 1961. That neo-classical bee. Journal of the History of Ideas, 22 (2): 262-266.

Kossman, E. H. 1960. The development of Dutch political theory in the seventeenth century. In Britain and the Netherlands, Vol. 1, eds. J. S. Bromley, and E. H. Kossman. London: Chatto \& Windus, 91-110.

Kramnick, Isaac. 1992. Bolingbroke and his circle: the politics of nostalgia in the age of Walpole. Ithaca: Cornell University Press.

Landreth, Harry. 1975. The economic thought of Bernard Mandeville. History of Political Economy, 7 (2): 193-208.

Letwin, William. 1963. The origins of scientific economics: English economic thought 1660-1776. London: Methuen.

Mandeville, Bernard. 1703. The pamphleteers: a satyr. London.

Mandeville, Bernard. 1709. The virgin unmask'd. London: F. Morphew, and J. Woodward.

Mandeville, Bernard. 1929 [1714-32]. The fable of the bees, or private vices, publick benefits, 2 Vols., ed. F. B. Kaye. Oxford: Oxford University Press.

McKendrick, Neil, John Brewer, and J. H. Plumb (eds.). 1992. The birth of a consumer society. London: Europa.

Mun, Thomas. 1664. England's treasure by forraigne trade. London: Printed by J. G. for Thomas Clark.

Ormrod, David. 2003. The rise of commercial empires: England and the Netherlands in the age of mercantilism, 1650-1770. Cambridge: Cambridge University Press.

Rose, Craig. 1999. England in the 1690s: revolution, religion, and war. Oxford: Blackwell.

Rostow, W. W. 1960. The stages of economic growth. Cambridge: Cambridge University Press.

Schama, Simon. 1987. The embarrassment of riches: an interpretation of Dutch culture in the golden age. New York: Knopf.

Scott, Jonathan. 2004. Downing, Sir George, first baronet (1623-1684). Oxford Dictionary of National Biography online edition.

http://www.oxforddnb.com/view/article/7981 (accessed 21 July 2008). 
Smith, Adam. 1963 [1776]. An inquiry into the nature and causes of the wealth of nations, 2 Vols. Illinois: Richard Irwin.

Stafford, J. Martin. 1997. Private vices, publick benefits? The contemporary reception of Bernard Mandeville. Solihull: Ismeron.

Temple, Sir William. 1972 [1673]. Observations upon the united provinces of the Netherlands, ed. G. N. Clark. Oxford: Oxford University Press.

Viner, Jacob. 1958. The long view and the short: studies in economic theory and policy. Illinois: Free Press.

Wilson, Charles. 1984. England's apprenticeship, 1603-1763. New York: Longman.

Alexander Bick is a $\mathrm{PhD}$ candidate in history at Princeton University. His current research is on the merchant-scholar Johannes de Laet and the politics of the Dutch West Indies Company in the 1640s.

Contact e-mail:<abick@princeton.edu> 